\title{
Crucial Residues in the Carboxy-terminal End of C1 Inhibitor Revealed by Pathogenic Mutants Impaired in Secretion or Function
}

\author{
Elisabeth Verpy, ${ }^{\star}$ Evelyne Couture-Tosi, ${ }^{*}$ Eric Eldering, ${ }^{\star}$ Margarita Lopez-Trascasa, ${ }^{\ddagger}$ Pierre Späth, ${ }^{\$}$ \\ Tommaso Meo, ${ }^{*}$ and Mario Tosi* \\ *Unité d'Immunogénétique et Institut National de la Santé et de la Recherche Médicale U. 276, Institut Pasteur, 75724, Paris Cedex 15, \\ France; ${ }^{\ddagger}$ Hospital La Paz, 29046, Madrid, Spain; and ${ }^{\S}$ Blood Transfusion Service SRC, Central Laboratory, 3000 Berne, Switzerland
}

\begin{abstract}
The last exon of the $\mathrm{CI}-\mathrm{INH}$ gene was screened for point mutations in 36 unrelated hereditary angioedema patients. Mutations were found in eight patients, predicting changes in the short COOH-terminal region which anchors the reactive site loop on its $\mathrm{COOH}$-terminal side. The effects of each of these mutations were examined in transiently transfected Cos-7 cells. Complete intracellular retention or degradation was observed with substitutions in the COOH-terminal strands 4B or 5B: Leu459 $\rightarrow$ Pro, Leu459 $\rightarrow$ Arg, and Pro467 $\rightarrow$ Arg were all blocked at early stages of intracellular transport, but differences in the immunofluorescence patterns indicated that a significant fraction of the Leu459 $\rightarrow$ Pro and of the Pro467 $\rightarrow$ Arg proteins reached a compartment distinct from the endoplasmic reticulum. In line with previous findings with $\alpha 1$-antitrypsin, chain termination within strand 5B resulted in rapid degradation. Mutant Val451 $\rightarrow$ Met, in strand 1C, and mutant Pro476 $\rightarrow$ Ser, replacing the invariant proline near the $\mathrm{COOH}$ terminus, yielded reduced secretion, but these extracellular proteins were unable to bind the target protease C1s. Presence of low levels of both dysfunctional proteins in patient plasmas defies the conventional classification of $\mathrm{C} 1$ inhibitor deficiencies as type $\mathrm{I}$ or type II. These data point to a key role of certain residues in the conserved COOH-terminal region of serpins in determining the protein foldings compatible with transport and proper exposure of the reactive site loop. (J. Clin. Invest. 1995. 95:350-359.) Key words: complement $\bullet \mathrm{Cl}$ inhibitor deficiency $\bullet$ hereditary angioedema $\bullet$ serpins

\section{Introduction}

$\mathrm{C} 1$ inhibitor ( $\mathrm{C} 1 \mathrm{inh}),{ }^{1}$ a highly glycosylated plasma protein is a member of the serpin family of protease inhibitors $(1-3)$. The
\end{abstract}

Address correspondence to Dr. Mario Tosi, Unité d'Immunogénétique, Institut Pasteur, 25, rue du Docteur Roux 75724 Paris Cedex 15. FAX: 1-40-61-32-36. E. Eldering's present address Department of Autoimmunediseases, Central Laboratory of the Netherlands Red Cross Blood Transfusion Service, Plesmanlaan 125 CX, Amsterdam, The Netherlands.

Received for publication 15 June 1994 and in revised form 20 September 1994.

1. Abbreviations used in this paper: $\alpha 1$-AT, $\alpha 1$-antitrypsin; ATIII, antithrombin III; $\mathrm{C} 1$ inh, $\mathrm{C} 1$ inhibitor protein; $C 1-I N H, \mathrm{Cl}$ inhibitor gene; $\mathrm{CCM}$, chemical cleavage of mismatches; endo $\mathrm{H}$, endoglycosidase $\mathrm{H}$; ER, endoplasmic reticulum; HAE, hereditary angioedema; serpin, serine protease inhibitor.

J. Clin. Invest.

(C) The American Society for Clinical Investigation, Inc

0021-9738/95/01/0350/10 \$2.00

Volume 95, January 1995, 350-359
P1 residue, i.e., the reactive center residue of the serpins, which is exposed on a loop $(4,5)$, is recognized by the substrate binding site of the target protease. Proteolytic attack on the peptidyl bond carboxy-terminal to the $P 1$ residue ensures the formation of a very stable complex between the inhibitor and the target protease. $\mathrm{C} 1$ inh is the only inhibitor of the $\mathrm{C} 1 \mathrm{r}$ and $\mathrm{C} 1 \mathrm{~s}$ subcomponents (6) of the first component of complement and therefore plays a key role in the control of the classical pathway of complement activation. It also plays a major role as an inhibitor of kallikrein and coagulation factor XIIa (for a review see reference 7 ).

Defects in the CI-INH gene (8) result in hereditary angioedema (HAE), a disease transmitted as an autosomal dominant trait and characterized by episodic acute subcutaneous or mucosal swellings (7). According to the plasma level of $\mathrm{C} 1$ inh two distinct forms of HAE were defined (9). The more common type $I$ is characterized by low plasma levels of the protein (5$30 \%$ of the normals) and the less frequent type II by normal or elevated levels of dysfunctional protein.

The CI-INH gene consists of 8 exons distributed over a DNA stretch of $17 \mathrm{~kb}$ and contains 17 repetitive elements of the Alu family within its introns (10). Most patients diagnosed as type II have single amino acid substitutions at $(11-14)$ or near $(15-17)$ the reactive center residue, although changes off the reactive center have also been reported to result in a dysfunctional $\mathrm{C} 1$ inh protein (18). Many different molecular defects determine type I HAE. Alu-mediated gene rearrangements (partial deletions or duplications) have been found in $15-20 \%$ of type I HAE families (19). The majority of HAE patients appears to carry point mutations or small deletions or insertions which may be located anywhere within $\mathrm{Cl}$-INH gene.

Exon 8, which encodes the reactive site of the $\mathrm{C} 1$ inh protein, was examined in patients who had failed to reveal major structural gene rearrangements (19). Here, we describe the detection of eight point mutations clustered downstream of the reactive site in the $\mathrm{COOH}$-terminal region of the $\mathrm{Cl}$ inh protein and characterize their phenotypes.

\section{Methods}

Subjects. We studied 36 unrelated type I HAE patients without gene alteration detectable by DNA blot analysis. Among these patients, seven had no familial history of the disease.

Amplification of genomic DNA by PCR. Exon 8 was amplified using oligonucleotide primers E1 (5' GTGAACTTGAACTAGAGAAAGC $\left.3^{\prime}\right)$ and E2 (5' TGAGGATCCCACGAACTGCCAG $\left.3^{\prime}\right)$ as shown in Fig. $1 \mathrm{~A}$. The $3^{\prime}$ ends of E1 and E2 are located $211 \mathrm{bp}$ downstream of the stop codon and 147 bp upstream of the first nucleotide of exon 8 , respectively (10). $1 \mu \mathrm{g}$ of genomic DNA isolated from peripheral white blood cells was used for amplification by PCR in a $100 \mu \mathrm{l}$ reaction with two units of Taq polymerase (AmpliTaq; Perkin Elmer, Norwalk, CT). The reaction was carried out in a Techne PHC1 or PHC2 thermocycler for 25 or 35 cycles with an annealing temperature of $60^{\circ} \mathrm{C}$. 
$\mathbf{A}$

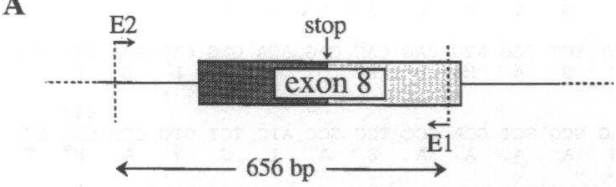

B
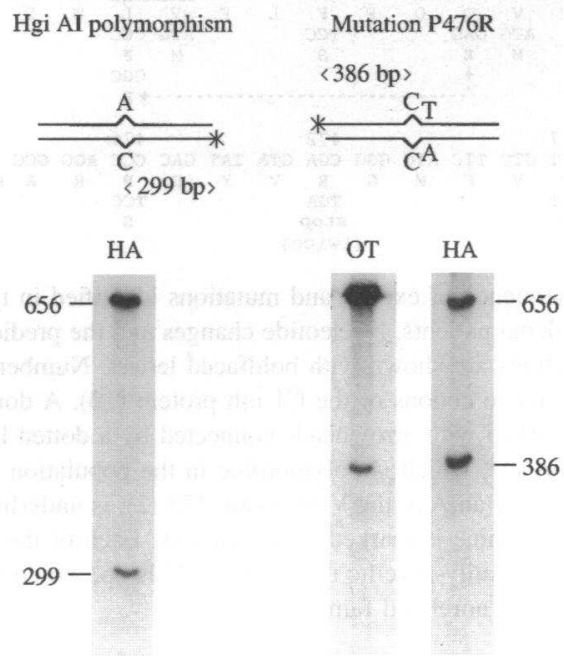

Figure 1. Detection of the HgiAI polymorphism and of patient-specific pathogenic mutations by chemical cleavage of mismatches (CCM). $(A)$ Schematic presentation of the region encompassing the coding portion of exon 8, that was amplified enzymatically from the patient genomic DNA. $(B)$ the schematic diagrams depict the heteroduplex molecules formed between the amplified patient DNA and the end-labeled antisense (left) or sense (right) wild-type probe. The HgiAI polymorphism (G or A at codon 458, see Fig. 2), was detected with the antisense probe upon hydroxylamine treatment. An example of mutation detection is provided by the $\mathrm{P} 467 \mathrm{R}$ mutation, revealed in the hydroxylamine reaction (HA) by the reactivity of a mismatched $\mathrm{C}$ at codon 467 in the sense probe (see Fig. 2). The adjacent $\mathrm{T}$ of the sense probe was also reactive with osmium tetroxide $(O T)$.

Chemical cleavage of mismatches. The probes and heteroduplexes between radiolabeled wild-type DNA and unlabeled patient DNA were produced as described by Grompe et al. (20). Modification of mismatched cytosine and thymine with hydroxylamine and osmium tetroxide, respectively, were carried out as described by Cotton et al. (21) with minor modifications: the heteroduplexes were incubated at $37^{\circ} \mathrm{C}$ for 1 to $3 \mathrm{~h}$ in a freshly prepared $2.5 \mathrm{M}$ hydroxylamine hydrochloride (Merck, Darmstadt, Germany) solution titrated to $\mathrm{pH} 6$ with diethylamine (Fluka AG, Buchs, Switzerland) or at $37^{\circ} \mathrm{C}$ for $1 \mathrm{~h}$ in $5 \mathrm{mM}$ Hepes, $\mathrm{pH}$ 8.0/0.5 mM EDTA/0.035\% osmium tetroxide (Aldrich, Chemical Co., Ltd., Milwaukee, WI)/3\% pyridine (Aldrich Chemical Co., Ltd.). The incubation time in piperidine (Merck) was reduced to $20 \mathrm{~min}$. Samples were electrophoresed in 5\% denaturing polyacrylamide gels.

Direct sequencing of PCR amplified DNA. The double stranded DNA product was gel purified and 0.2 pmoles were subjected to $25-35$ cycles of asymmetric amplification with 25 pmoles of a single primer in a 50- $\mu$ l reaction volume. Single strand DNA was precipitated in $2 \mathrm{M}$ ammonium acetate with one volume of ethanol and the dried DNA pellet was resuspended in $5 \mu 1 \mathrm{H}_{2} \mathrm{O}$ and sequenced using the dideoxy chain termination method (Sequenase 2.0; US Biochemical Corp., Cleveland, $\mathrm{OH}$ ).

$\mathrm{Cl}$ inh expression plasmids. A cDNA expression plasmid containing the complete coding sequence of a wild-type $\mathrm{C} 1$ inh was constructed using the pSVL vector (Pharmacia LKB Biotechnology Inc., Piscataway, $\mathrm{NJ})$. This construct was similar to a previously described expression plasmid (22), except that the full-length cDNA (2) was transferred from a pBluescript KS + (Stratagene, La Jolla, CA) intermediate vector into pSVL by using the unique XhoI and XbaI sites. The PCR amplified exon 8 fragments (see Fig. $1 \mathrm{~A}$ ) were cleaved at the EcoRI site at the intron 7/exon 8 boundary $(10)$ and used to replace the corresponding fragment of the wild-type expression plasmid, from the unique EcoRI site of the cDNA to the unique SmaI site of pSVL. The EcoRI site present in the pSVL vector had been destroyed by partial digestion and religation after filling-in the $5^{\prime}$ overhangs. Clones corresponding to mutant alleles were selected using enzymes which recognized either the mutation directly or the associated allelomorphism at the HgiAI site in exon 8, which was known from previous pBluescript $\mathrm{KS}+$ plasmid subcloning. The entire coding portion exchanged was sequenced according to the Sequenase protocol (U. S. Biochemical Corp.). Clones differing only for the biallelic HgiAI polymorphism at codon 458 were used as controls and did not differ in their pattern of expression. In the case of a patient with a double point mutation (family F40), the mismatch primer method (23) was used to introduce separately each mutation in the PCR amplified exon 8 fragment. The primers containing the mutations (underlined) of this patient were on the coding strand E4 ( $5^{\prime}$ TCTTTGAAGTGGAGCAGCCCT 3') and E6 (5' TTCCTCTTCGTGCGCTGGGA $3^{\prime}$ ).

Transient expression in COS-7 cells, metabolic labeling, and immunoprecipitation. Cos-7 cells were seeded at $3.10^{5}$ per $25 \mathrm{~cm}^{2}$ flask in DME plus $10 \%$ fetal calf serum one day before transfection with $5 \mu \mathrm{g}$ of DNA using DEAE dextran (24). The calcium phosphate mediated transfection method was also used in some experiments with the following modifications (25): the precipitates were formed on ice for $90 \mathrm{~min}$ and cells were exposed to precipitates for $14-16 \mathrm{~h}$ in $100 \mu \mathrm{M}$ chloroquine (Sigma Chemical Co., St. Louis, MO). $55 \mathrm{~h}$ after tranfection, cells were metabolically labeled overnight with $100 \mu \mathrm{Ci} / \mathrm{ml}$ of $\left[{ }^{35} \mathrm{~S}\right]-$ methionine (specific activity $>1,000 \mathrm{Ci} / \mathrm{mmole}$; Amersham Corp., Arlington Heights, IL). Culture medium $(1.5 \mathrm{ml})$ was removed, cells were washed with PBS and lysed at $4^{\circ} \mathrm{C}$ by shaking for $1 \mathrm{~h}$ in $1 \mathrm{ml}$ of 10 $\mathrm{mM}$ Tris-HCl, $\mathrm{pH} 7.2,0.15 \mathrm{M} \mathrm{NaCl}, 0.02 \% \mathrm{NaN}_{3}, 4$ mM EDTA, 4 $\mathrm{mM}$ benzamidine- $\mathrm{HCl}, 0.5 \%$ NP40, $4 \mathrm{mM}$ PMSF (Sigma Chemical Co.). Culture media and cell lysates were centrifuged at 5,000 rpm for $20 \mathrm{~min}$ and cell lysates were treated with $1 \%$ SDS (final concentration) for $20 \mathrm{~min}$ at room temperature. Cell lysates were diluted to $5.5 \mathrm{ml}$ of $30 \mathrm{mM}$ Hepes, $\mathrm{pH} 8.0,55 \mathrm{mM} \mathrm{NaCl}, 20 \%$ fetal calf serum, $1.1 \% \mathrm{NP} 40$, and culture media $(1.5 \mathrm{ml})$ were diluted to $4 \mathrm{ml}$ of $55 \mathrm{mM} \mathrm{NaCl}, 20 \%$ fetal calf serum, $0.4 \%$ NP40 (final concentrations). Culture media and cell lysates were incubated overnight with constant mixing at $4^{\circ} \mathrm{C}$ with $5 \mu$ l of goat anti-human $\mathrm{Cl}$ inh IgG fraction (Atlantic Antibodies/ INCSTAR, Stillwater, Minnesota; total protein $14.3 \mathrm{mg} / \mathrm{ml}$ ). After addition of $50 \mu \mathrm{l}$ of protein A-Sepharose (1:1 dilution in $40 \mathrm{mM}$ Hepes, $\mathrm{pH} 8.0$; pretreated overnight at $4^{\circ} \mathrm{C}$ with $15 \%$ fetal calf serum in 40 $\mathrm{mM}$ Hepes, $\mathrm{pH}$ 8.0) mixing was continued at room temperature for 2.5 h. Immunoprecipitates were treated as described (26) and samples were analyzed on $10 \%$ reducing SDS-polyacrylamide gels.

Pulse-chase studies. $65 \mathrm{~h}$ after transfection cells were pulse-labeled with $150 \mu \mathrm{Ci} / \mathrm{ml}$ of $\left.{ }^{35} \mathrm{~S}\right] \mathrm{methionine}$ for $15 \mathrm{~min}$, and chased for various times up to $8 \mathrm{~h}$.

Endoglycosidase $H$ treatment. Subconfluent Cos-7 cells in $75 \mathrm{~cm}^{2}$ flasks were transfected with calcium phosphate precipitates of DNA (15 $\mu \mathrm{g}$ for each plasmid). $65 \mathrm{~h}$ after transfection cells were labeled with $100 \mu \mathrm{Ci} / \mathrm{ml}$ of $\left[{ }^{35} \mathrm{~S}\right]$ methionine for $5 \mathrm{~h}$. After immunoprecipitation of intracellular $\mathrm{C} 1$ inh the material was solubilized by incubating the pellets in $30 \mu \mathrm{l}$ of $15 \mathrm{mM}$ betamercaptoethanol/ $0.5 \%$ SDS at $96^{\circ} \mathrm{C}$ for $5 \mathrm{~min}$. One third of the sample was incubated in $50 \mu \mathrm{l}$ of $50 \mathrm{mM}$ sodium citrate pH 5.5, $2 \%$ Triton X-100, $5 \mathrm{mM} \mathrm{PMSF}$ at $37^{\circ} \mathrm{C}$ for $20 \mathrm{~h}$, either with or without $2.5 \mathrm{mU}$ of endoglycosidase $\mathrm{H}$ (endo $\mathrm{H}$; Boehringer Mannheim, Mannheim, Germany).

Immunofluorescence microscopy. Cos-7 cells grown and transiently transfected on coverslips using the DEAE-dextran method were washed three times in PBS containing $0.1 \%$ bovine serum albumin (PBS/BSA), fixed $30 \mathrm{~min}$ at $4^{\circ} \mathrm{C}$ with $3.7 \%$ paraformaldehyde $/ 0.03 \mathrm{M}$ sucrose in 
PBS, rinsed twice with PBS/BSA and then incubated for $2 \mathrm{~min}$ in $50 \mathrm{mM}$ $\mathrm{NH}_{4} \mathrm{Cl} / \mathrm{PBS}$. After two washes in PBS/BSA, cells were permeabilized by incubation in $0.05 \%$ saponin (Sigma Chemical Co.)/ PBS/BSA for 15 $\min$ at $37^{\circ} \mathrm{C}$. Cells were then incubated for $1 \mathrm{~h}$ with goat anti-C1 inh, washed twice in $0.05 \%$ saponin/PBS/BSA, incubated with FITC conjugated rabbit anti-goat IgG (Biosys, Compiègne, France) and RITC labeled wheat germ agglutinin (Sigma Chemical Co.) for $60 \mathrm{~min}$, washed twice in PBS and then mounted onto glass slides with $10 \%$ 1,4-diazabicyclo-(2.2.2) octane (Dabco; Sigma Chemical Co.). Cells were viewed on a fluorescence microscope (Olympus) or on a confocal laser scanning microscope (Leica) using an interferential narrow-band filter (535 $\mathrm{nm} \pm 8$ ) for fluorescein and a long pass filter (RG590) for rhodamine.

Cls binding assay. Cls binding assay was performed as described (27). Transiently transfected Cos-7 cells were metabolically labeled overnight. Tween $20(0.1 \% \mathrm{vol} / \mathrm{vol})$ was added to the conditioned medium and $300-500 \mathrm{ml}$ were incubated at $37^{\circ} \mathrm{C}$ for $3 \mathrm{~h}$ with or without 1 or $5 \mu \mathrm{g}$ of activated C1s. After addition of $5 \mathrm{mM}$ PMSF samples were immunoprecipitated overnight at $4^{\circ} \mathrm{C}$ with monoclonal antibody RII-Sepharose (28) which recognizes all forms of $\mathrm{Cl}$ inh (native, complexed, and cleaved). Samples were analyzed on $7.5 \%$ nonreducing gels.

\section{Results}

Screening of HAE patients for mutations affecting the $\mathrm{COOH}$ terminal region of the $C 1$-inhibitor protein. The coding sequence of exon 8, the $3^{\prime}$ most exon of $C 1-I N H$ gene was PCR amplified, as shown in Fig. $1 \mathrm{~A}$, from genomic DNA of 36 unrelated type I HAE patients who had failed to reveal gene deletions or duplications (19). The resulting fragment of 656 bp was subjected to chemical cleavage of mismatches (CCM, reference 21 ). In addition to the cleavage product expected from the $\mathrm{G}$ to $\mathrm{A}$ transition which is responsible for the known HgiAI allelomorphism (2), mismatches were detected in eight patients (see the example in Fig. $1 B$ ). In one of these (not shown), the CCM pattern indicated the presence of two sites of mutation distinct from the G/A allelomorphism. No additional mutation was found in this region when all 36 unrelated patients were re-examined by using the recent FAMA (Fluorescence Assisted Mismatch Analysis) methodology (29), although this more powerful method revealed patient-specific mutations, located in other exons, in 33 patients of this group (data not shown).

To identify the mutations, sequencing was performed, directly on the PCR products, in the regions where the mismatches had been localized. Eight patient-specific nucleotide substitutions were identified (Fig. 2), of which the $\mathrm{C}$ to $\mathrm{T}$ transition, responsible for the R472stop change, was found in two unrelated patients and the two which are connected with a dotted line in Fig. 2 were found in the same patient, confirming the complex CCM pattern alluded to above. This patient carries a $\mathrm{C}$ to $\mathrm{G}$ transversion that changes the glutamine 452 to a glutamic acid and $\mathrm{a} T$ to $\mathrm{G}$ transversion that produces a leucine to arginine substitution at position 459. This latter mutation destroys the recognition site for the enzyme HgiAI (GTGCTC underlined in Fig. 2) which is polymorphic in the normal population (2). In another patient a mutation was found, again at the fifth position of the HgiAI restriction site. In this case, the $\mathrm{T}$ to $\mathrm{C}$ transition produces a leucine to proline substitution. The other mutations identified are shown in Fig. 2. It is striking that all the mutations were found located downstream of the reactive site argine 444 , marked with an asterisk in Fig. 2.

To reconstruct the patient haplotypes, a 434-bp-long segment obtained by BglII digestion of the PCR amplified exon 8

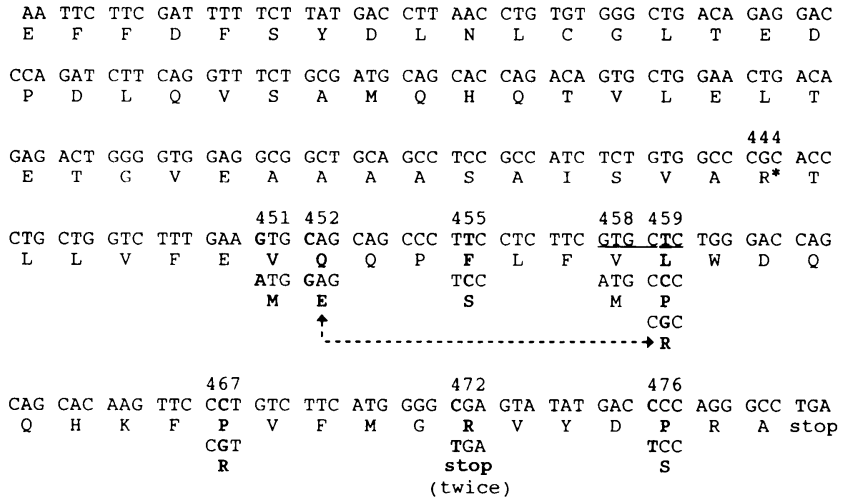

Figure 2. Coding sequence of exon 8 and mutations identified in type I hereditary angioedema patients. Nucleotide changes and the predicted amino acid substitutions are shown with boldfaced letters. Numbers above the triplets refer to codons of the $\mathrm{C} 1$ inh protein (10). A double point mutation is marked with arrowheads connected by a dotted line. An HgiAI restriction site, which is polymorphic in the population due to the presence of a $\mathrm{G}$ or an $\mathrm{A}$ at the V/M codon 458 (2), is underlined. The reactive center arginine is marked by an asterisk. Each of the mutations shown was family-specific except the R472stop, which was found in two apparently unrelated families.

sequence was cloned into the plasmid pBluescript KS+ (Stratagene). These clones allowed us to establish by sequence analysis that, in the case of the patient with the double point mutation, both changes were on the same chromosome. It was also noted that all mutations in exon 8 were associated with a $G$ at the first position of the polymorphic $\mathrm{HgiAI}$ site $\left(\mathrm{HgiAI}^{+}\right.$alleles). All patients appeared to be heterozygous for the HgiAI site except the two unrelated patients with the R472stop mutation. The latter, however, generates a new HphI site. These observations facilitated the selection of the corresponding constructs for expression studies. Clones with the double point mutation were identified because the mutation at codon 459 destroys the HgiAI site. Similarly, the L459P mutant clones were also $\mathrm{HgiAI}^{-}$. Thus, the two patients with mutations in this codon were not HgiAI heterozygotes, according to the HgiAI polymorphism. The other constructs were selected either by HphI digestion for the R472 stop mutation or by virtue of the association of the mutation with the HgiAI+ alleles. The entire portion exchanged around exon 8 was sequenced in each of the expression plasmids selected.

Effects of the mutations on intracellular transport and stability of the protein. To characterize the functional correlates of each mutation, transient expression studies were carried out in Cos-7 cells. In the case of the double point mutation (see Fig. 2) the consequences of each change were tested separately. Fig. 3 shows that mutations in the carboxyl end of the $\mathrm{C} 1$ inh protein affect protein stability and/or secretion. Compared with wild-type $\mathrm{C} 1$ inh, the V451M and P476S mutant proteins were only partially secreted, while only trace amounts were detected in the extracellular medium for the F455S mutant and no protein was found secreted significantly above the Cos-7 background for the R472stop , L459P, P467R, and Q452E+L459R mutants. In the latter case, expression testing of each mutation separately showed that the L459R mutation was responsible for the effect observed when both mutations were expressed together. The 


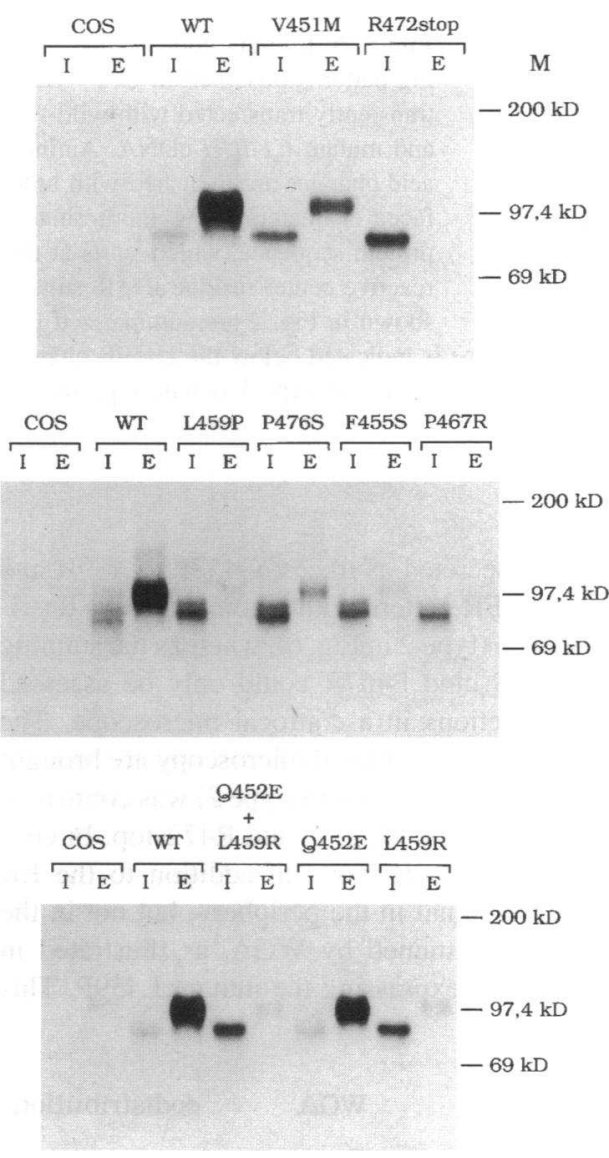

Figure 3. Expression in Cos-7 cells of wild-type and mutant $\mathrm{C} 1$ inh proteins. Untransfected Cos-7 cells (COS) and cells transiently transfected with wild-type (WT) or mutant $C 1-I N H$ cDNA expression vectors were labeled overnight with $\left[{ }^{35} \mathrm{~S}\right]$ methionine and $\mathrm{C} 1$ inh present in intracellular lysates $(I)$ and extracellular media $(E)$ was immunoprecipitated with a polyclonal anti $\mathrm{C} 1$ inh. Samples were analyzed on $10 \%$ reducing SDS-polyacrylamide gels. Molecular masses indicated at the right side of the gels are from marker proteins $(M)$. Each panel is from a different experiment. A very weak reactivity of the polyclonal antibodies with $\mathrm{C} 1$ inh secreted by the Cos-7 cells was observed.

Q452E protein seemed to behave as wild-type $\mathrm{Cl}$ inh, in that it was efficiently secreted.

Fig. 4 shows pulse-chase experiments in which Cos-7 cells transfected with wild-type, R472stop, V451M, and P476S expression plasmids were labeled for $15 \mathrm{~min}$ and chased up to 8 $h$. The major band observed in the intracellular lysates corresponds to a partially glycosylated protein. The fully glycosylated $\mathrm{C} 1$ inh cannot be detected in the intracellular lysates of wild-type transfected cells, indicating that it is rapidly exported to the extracellular medium. After a $4 \mathrm{~h}$ chase, nearly all labeled wild-type $\mathrm{Cl}$ inh is secreted. The R472stop protein, which is not secreted, is degraded intracellularly whereas the intracellular forms of the partially secreted V451M and P476S proteins are more stable. The latter two proteins begin to appear significantly in the extracellular medium after a $1 \mathrm{~h}$ chase period, like wildtype $\mathrm{C} 1 \mathrm{inh}$. In this pulse-chase experiment and in other experiments with $\mathrm{Cl}$ inh mutants, the defective proteins accumulating within the cell were always found to be partially glycosylated. To examine if they accumulate at an early step of intracellular

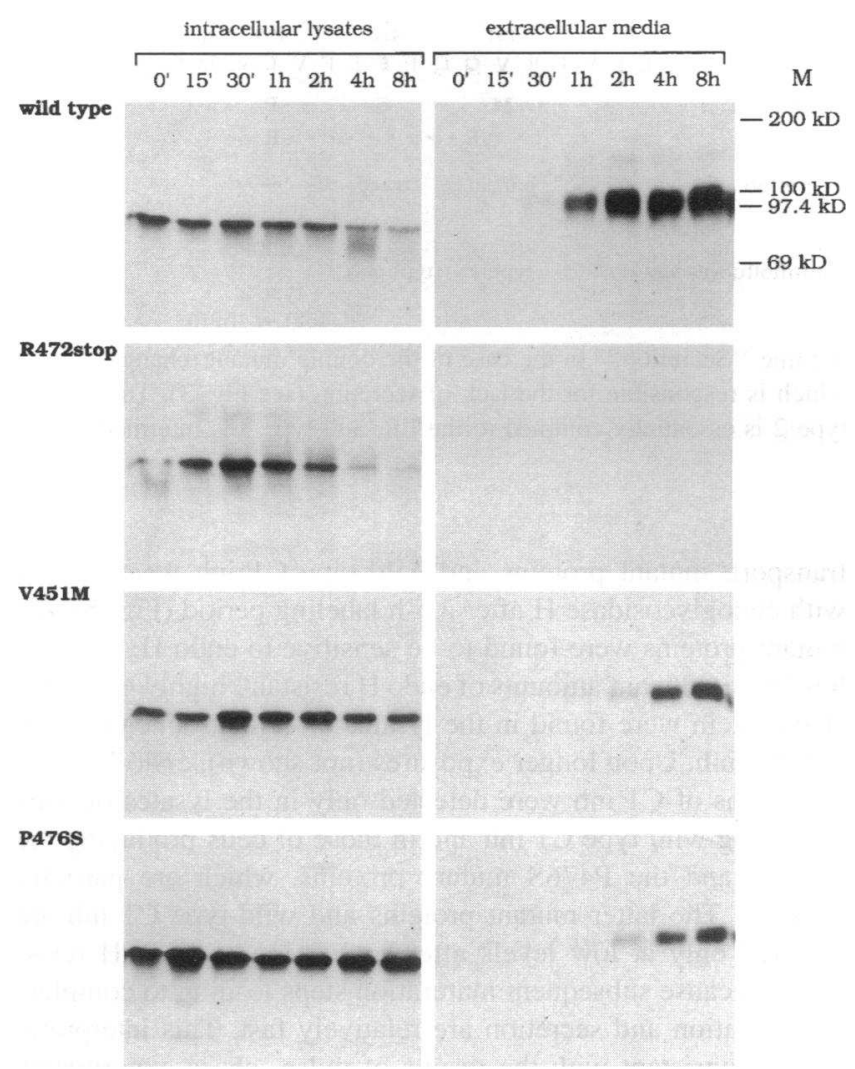

Figure 4. Pulse-chase labeling of wild-type, R472stop, V451M, and P476S mutant $\mathrm{C} 1$ inh in transfected Cos-7 cells. $65 \mathrm{~h}$ after transfection, cells were labeled for $15 \mathrm{~min}$ with $\left[^{35} \mathrm{~S}\right]$ methionine. After labeling, cells were either immediately lysed $\left(0^{\prime}\right)$ or chased for various times $\left(15^{\prime}\right.$ to $8 \mathrm{~h})$. Cell lysates and extracellular media were immunoprecipitated with a polyclonal anti $\mathrm{Cl}$ inh and analyzed on $10 \%$ reducing SDS-polyacrylamide gels. Molecular masses indicated on the right side of the upper gel are from marker proteins $(M)$.

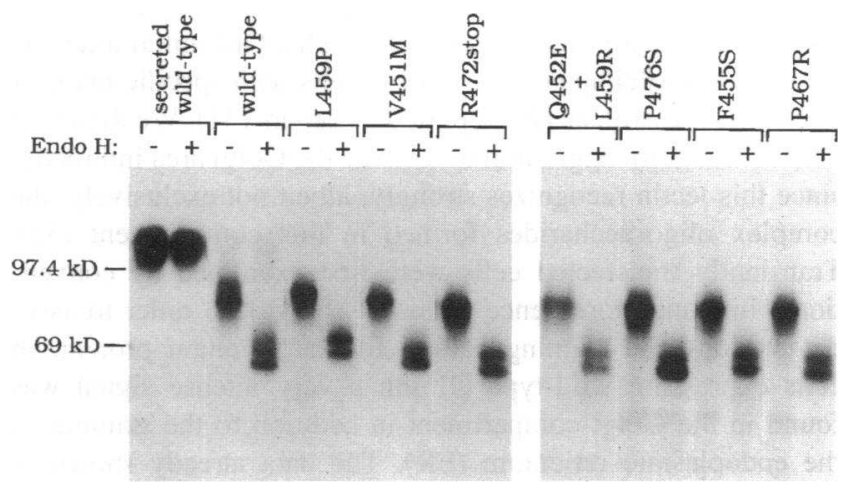

Figure 5. Endoglycosidase $\mathrm{H}$ sensitivity of intracellular wild-type and mutant $\mathrm{C} 1$ inh. Cells were metabolically labeled sixty-five hours posttransfection with $\left[{ }^{35} \mathrm{~S}\right]$ methionine for $5 \mathrm{~h}$. Immunoprecipitates from lysates were incubated for $20 \mathrm{~h}$ at $37^{\circ} \mathrm{C}$ either with (+) or without (-) endo $\mathrm{H}$. Secreted wild-type $\mathrm{C} 1$ inh was used as a negative control. Highly glycosylated, endo $\mathrm{H}$ resistant $\mathrm{Cl}$ inh is present at low but significant levels in the lanes corresponding to wild-type transfections. Note that the gel mobility is slightly modified by loss or acquisition of a proline residue. The apparent molecular mass of in vitro synthesized $\mathrm{C} 1$ inh has been estimated to be $64 \mathrm{kD}$ (1). 


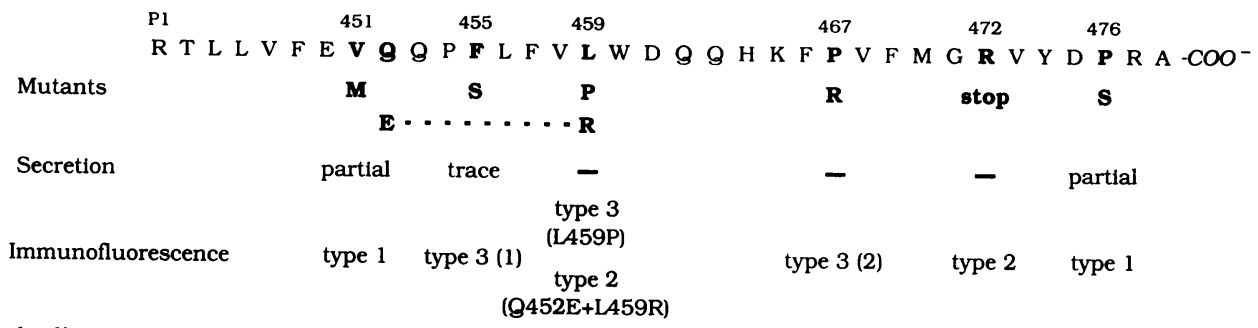

Figure 6. Immunofluorescence staining patterns observed in Cos-7 cells transiently transfected with wild-type and mutant $C 1-I N H$ cDNA. Amino acid changes are indicated with boldfaced characters below the normal protein sequence, which starts at the reactive center residue $P 1$. Results shown in Fig. 2 are summarized in

the line "Secretion." In the case of the double mutant (changes connected with a dotted line) the phenotype is indicated below the L459R change, which is responsible for the lack of secretion (see Fig. 3). Three types of immunofluorescence staining were observed: type 1 is wild-type like, type 2 is essentially confined to the ER, and type 3 is intermediate (see Fig. 7 and text).

transport, mutant proteins and wild-type $\mathrm{C} 1$ inh were treated with endoglycosidase $\mathrm{H}$ after a 5-h labeling period (Fig. 5). All mutant proteins were found to be sensitive to endo $\mathrm{H}$, whereas low but significant amounts of endo $\mathrm{H}$ resistant, highly glycosylated protein were found in the lysates of cells producing wildtype $\mathrm{C} 1$ inh. Upon longer exposures (not shown), endo $\mathrm{H}$ resistant forms of $\mathrm{C} 1$ inh were detected only in the lysates of cells producing wild type $\mathrm{C} 1$ inh and in those of cells producing the V451M and the P476S mutant proteins, which are partially secreted. The latter mutant proteins and wild-type $\mathrm{Cl}$ inh are detected only at low levels after conversion to endo $\mathrm{H}$ resistance, because subsequent maturation steps leading to complete glycosylation and secretion are relatively fast. This interpretation is consistent with the results of pulse-chase experiments like the one shown in Fig. 4, in which longer exposures (not shown) revealed only a faint, continuous distribution of highly glycosylated wild-type intracellular C1 inh. Given that wildtype $\mathrm{C} 1$ inh produced in transfected Cos cells is efficiently secreted after tunicamycin treatment (22) it is unlikely that mutant proteins are blocked in their intracellular transport for lack of proper glycosylation. More likely, the endo $\mathrm{H}$ sensitivity suggests that they never reach the medial Golgi where conversion to endo $\mathrm{H}$ resistance occurs (30).

The sites of intracellular retention or degradation of the mutant proteins were examined by immunofluorescence microscopy in transiently transfected Cos-7 cells. Our initial attempts to stain the Golgi apparatus of these cells with specific markers were unsuccessful, as also reported by others (31). We therefore used wheat germ agglutinin to localize the Golgi area indirectly, since this lectin recognizes strongly, albeit not exclusively, the complex oligosaccharides formed in this compartment (32). Transiently transfected cells were first examined by conventional immunofluorescence (data not shown), in order to asses the predominant staining pattern for each mutant protein. In cells expressing wild-type $\mathrm{C} 1$ inh a very intense signal was found in the Golgi compartment in addition to the staining of the endoplasmic reticulum (ER). The data already shown in Figs. 4 and 5 suggest that the strong $\mathrm{C} 1$ inh staining of the Golgi area is due to high local concentrations of incompletely glycosylated, endo $\mathrm{H}$ sensitive transient forms of the wild-type protein. As expected, partially secreted proteins (V451M and P476S) gave a staining pattern similar to the one obtained with wild-type $\mathrm{Cl}$ inh (type 1 in Fig. 6). With these mutants both the ER and the Golgi area were stained but, compared to wildtype $\mathrm{C} 1$ inh, staining was more homogeneous, i.e., the relative intensity of the ER to the Golgi staining was higher than with the normal protein. Two distinct patterns were obtained for proteins not secreted or secreted as traces: Q452E+L459R and R472stop gave a typical ER pattern with a homogeneous distribution of the fluorescence (type 2 in Fig. 6), whereas the staining pattern of L459P, F455S, and P467R could only be assessed by examining optical sections in a confocal microscope. The results of the conventional and confocal microscopy are brought together in Fig. 6 . The typical ER pattern (type 2) was confirmed for the mutants Q452E+L459R (Fig. 7) and R472stop. In contrast, F455S, L459P and P467R gave, in addition to the ER staining, a rather intense signal in the periphery, but not in the central area, of the region stained by WGA, as illustrated in Fig. 7 by a transfected cell expressing the mutant L459P. This

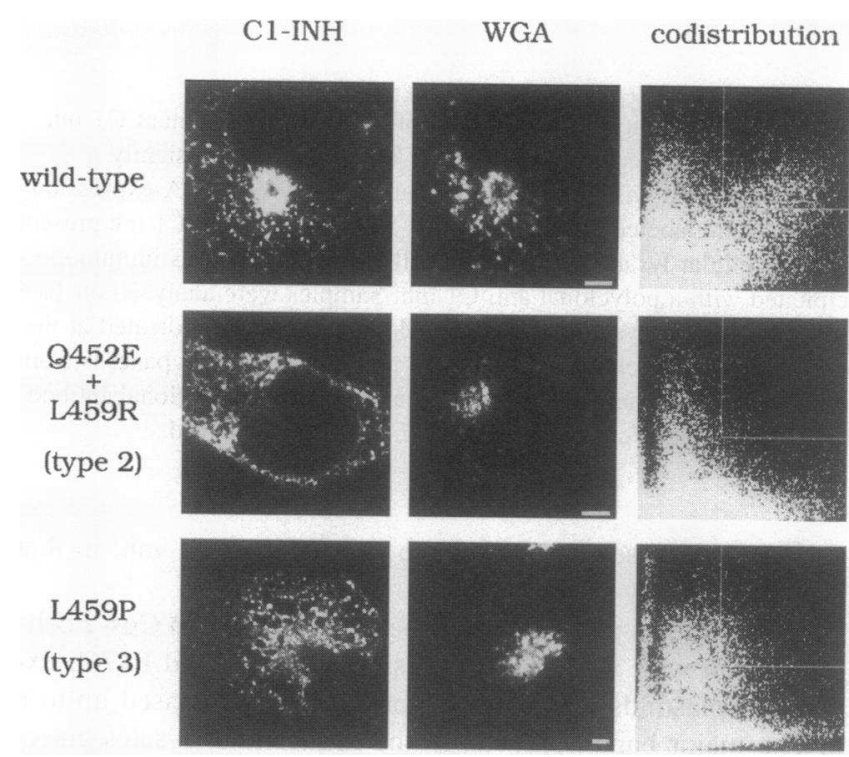

Figure 7. Intracellular localization of wild-type, Q452E+L459R and L459P C 1 inh by confocal immunofluorescence microscopy. Transiently transfected Cos-7 cells were treated as described in Methods. The wheat germ agglutinin (WGA) was used as an indirect Golgi marker. The micrographs presented are from optical sections of the cells. The panels on the right are cytofluorograms of the optical sections shown and represent the co-distribution of the intensities of both fluorescences with FITC on the abscissa (C1 inh) and RITC on the ordinate (WGA). Squares in the upper right corner display the points with intensities in both fluorescences above $40 \%$ of the maxima. Bar, $5 \mu \mathrm{m}$. The type 2 pattern (lack of co-distribution) indicates accumulation of $\mathrm{C} 1$ inh mainly in the ER. The type 3 pattern (partial co-distribution) is defined by presence of intense $\mathrm{Cl}$ inh staining also in the periphery, but not in the central area of the region stained by WGA. 


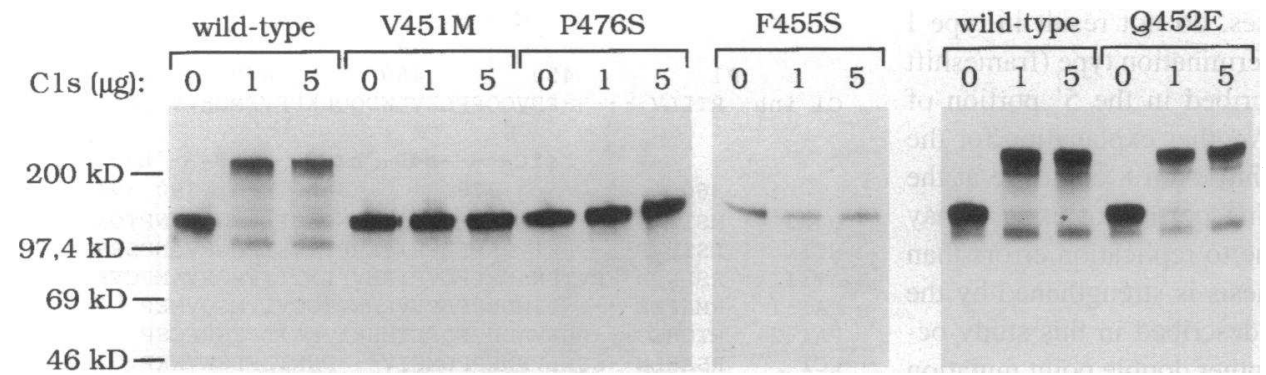

Figure 8 . Binding of the wild-type and mutant $\mathrm{Cl}$ inh proteins to the target protease $\mathrm{C} 1 \mathrm{~s}$. Metabolically labeled transfection media were incubated without (-) or with 1 or $5 \mu \mathrm{g}$ of $\mathrm{C} 1 \mathrm{~s}$ for $3 \mathrm{~h}$ at $37^{\circ} \mathrm{C}$. Samples were immunoprecipitated with monoclonal antibody RII, which recognizes all forms of $\mathrm{Cl}$ inh, and analyzed on $7.5 \%$ nonreducing SDS-polyacrylamide gels. The data for mutants-

V451M, F455S, P476R, and for mutant Q452E are from independent experiments. Note that the latter mutant protein has not been observed as an independent natural mutant.

pattern is designated as type 3 in Figs. 6 and 7. These observations indicate that, depending on the nature of the mutation, either the mutant $\mathrm{Cl}$ inh protein is unable to leave the ER or it reaches another compartment topologically closely associated to the Golgi complex. For lack of more precise identification of this compartment, the assignment of three mutant proteins to the same type 3 pattern does not imply that their intracellular localization is identical. In addition, in the cases of F455S and P467R, some cellular variation in the staining pattern was observed, possibly reflecting different levels of expression of the protein among transfected Cos cells. A typical ER pattern (type 2 in Fig. 6) was sometimes observed with mutant P467R, although it gave, in the great majority of transfected cells, a type 3 pattern. Moreover, a fraction of $\mathrm{F} 455 \mathrm{~S}$ transfected cells, which secrete traces of $\mathrm{Cl}$ inh, had a pattern closer to the type 1 staining.

The partially secreted mutant proteins V451M and P476S are dysfunctional. The ability of the partially secreted V451M and P476S mutant $\mathrm{C} 1$ inh protein to bind the target protease $\mathrm{C} 1 \mathrm{~s}$ was investigated. In addition, mutant F455S, which is secreted only in trace amounts, and mutant Q452E, which is normally secreted, were also tested for functional activity. Fig. 8 demonstrates that the V451M, P476S, and F455S mutant proteins have remarkably reduced capacity to bind $\mathrm{C} 1 \mathrm{~s}$ and do not behave as substrates. A very faint band at the position of the $\mathrm{C} 1 \mathrm{inh} / \mathrm{C} 1 \mathrm{~s}$ complex was seen upon long exposures but, relative to the amount of $\mathrm{C} 1$ inh present in the assay, only the F455S mutant, which is secreted in trace amounts, may have some residual capacity to bind $\mathrm{C} 1 \mathrm{~s}$. In all cases, the amount of complexes was the same when the extracellular medium was incubated with 1 or $5 \mu \mathrm{g}$ of $\mathrm{Cls}$, ruling out the possibility that the trace reactivities of these mutant $\mathrm{C} 1$ inhibitors with $\mathrm{C} 1 \mathrm{~s}$ are due to selective recognition of a minor fraction of $\mathrm{C} 1 \mathrm{~s}$ which would have an adequate conformation for these mutants. Thus, the secreted fractions of both mutant proteins V451M and P476S are dysfunctional. Moreover, like the recently described P10 mutant $\mathrm{C} 1$ inhibitor Mo (34), they do not behave as substrates. Fig. 8 also shows that the secretion-competent Q452E mutation (Fig. 3), found in association with the pathogenic L459R mutation, also has no effect on the capacity of $\mathrm{Cl}$ inh to bind $\mathrm{Cls}$.

$\mathrm{C} 1$ inhibitor antigenic levels in the plasmas of patients from families F10 and F30, who carry the V451M and the P476S mutation, respectively, were determined by RIA with mAbRII as described $(28,33)$ and were found to be in the $25-30 \%$ range of normals. Their functional $\mathrm{Cl}$ inh levels, determined by RIA using Sepharose 4B-bound C1s (28) were moderately but consistently lower than the antigenic $\mathrm{C} 1$ inh levels (data not shown). Since no significant increase of cleaved $\mathrm{C} 1$ inh or of $\mathrm{C} 1 \mathrm{~s}-\mathrm{Cl}$ inh, kallikrein-C1 inh or Factor XII-Cl inh complexes was found (not shown) these data suggested the presence of low levels of dysfunctional $\mathrm{Cl}$ inh in their plasmas. Furthermore, the analogy with the nonsubstrate-like behavior of the P10 mutant C1 inhibitor Mo (34) prompted us to examine the recombinant proteins $\mathrm{V} 451 \mathrm{M}$ and $\mathrm{P} 476 \mathrm{~S}$ and the plasmas of patients carrying these mutations by using the monoclonal antibody KOK12, which is specific for cleaved or complexed normal $\mathrm{C} 1$ inh and recognizes the uncleaved mutant $\mathrm{C} 1$ inhibitor Mo (34). These studies demonstrated that the recombinant V451M and P476S proteins are in a conformation which is recognized by KOK12 (34a) and confirmed the presence, in plasmas from patients carrying these mutations, of significant levels of altered $\mathrm{C} 1$ inh which is recognized by this conformation-specific monoclonal antibody (34b).

\section{Discussion}

Recent genetic studies of HAE underscore the heterogeneity of this disease, at the molecular level. Screening of HAE patients for mutations in the $C 1-I N H$ gene should provide to families the possibility of early DNA diagnosis. Moreover, in patients without family history (at least 7 out of 36 unrelated patients in the group described here), mutation screening of all exons of the CI-INH gene is a rapid and efficient way to prove the genetic nature of the disease. Mutations resulting in amino acid substitutions, even if patient-specific, often require additional investigations in order to demonstrate that they are responsible for the disease. Thus, mutation screening and transfection studies to determine the biochemical consequences of the predicted amino acid substitutions were applied initially to exon 8 , which codes for a relatively large carboxy-terminal portion of the $\mathrm{C} 1$ inh protein, including the reactive site loop.

While the number of unrelated patients with a mutation in exon $8(8 / 36)$ is roughly proportional to the fraction of $C 1$ INH coding sequence screened (84 out of 478 amino acids are encoded in exon 8) the distribution of these mutations is highly unbalanced. All were found clustered downstream of the reactive site residue R444. However, several single nucleotide substitutions affecting the reactive site residue $\mathrm{R} 444$ itself (11$14)$, or upstream residues within $\beta$ strand $4 \mathrm{~A}(15-17,35)$, have been described in type II patients. In these cases the mutations affected the reactive site loop, leading to production of a secreted but dysfunctional protein. Apparently, amino acid substitutions within the exposed loop or in the hinge region have less deleterious effects on secretion than changes near the carboxyl 
end of the protein and, in most cases, do not result in type I HAE. A few mutations of the chain termination type (frameshift or stop codon) have also been described in the $5^{\prime}$ portion of exon 8 of type I patients (36-38). Another explanation for the biased distribution of mutations within exon 8 could lie at the DNA level. The 3' half of the coding portion of exon 8 may be, for structural reasons, more prone to replication errors than the $5^{\prime}$ half (see Fig. 2). This hypothesis is strengthened by the fact that the double point mutation described in this study occurred de novo (data not shown). Another double point mutation in the reactive center region has been described in a type II patient, i.e., with high plasma levels of a dysfunctional $\mathrm{C} 1$ inh protein, but the time of occurrence of these mutations in the family was not known (35). In another study a 34-bp deletion and a 20-bp duplication found in the reactive center coding region helped identify a palindromic sequence capable of forming a strong secondary structure (35a). Whether this potential secondary structure in the reactive center coding region predisposes to mutations in the $3^{\prime}$ half of the coding portion of exon 8 is unknown. Only one of the mutations described in our study, i.e., the one responsible for R472stop, was at a hypermutable $\mathrm{CpG}$ dinucleotide and was found twice in apparently unrelated patients. Moreover, the same mutation has also been found in another study (35a).

The classification of HAE patients into separate groups (type I and type II) according to the quantitative plasma levels (low or high) of $\mathrm{C} 1$ inh does not always correlate with distinct categories of molecular defects. For example, mutants V451M and P476S (Fig. 8) are secreted at low levels but are dysfunctional and therefore determine a compound phenotype associating the dysfunctional condition of type II with the strongly reduced plasma levels of type I HAE. This dysfunctional fraction can readily be detected (Eldering, E., E. Verpy, D. Roem, T. Meo, and $\mathrm{M}$. Tosi, manuscript submitted for publication) by using the conformation-specific monoclonal antibody KOK 12 (34, and references therein).

The precise mechanisms leading, in HAE patients, to functional $\mathrm{C} 1$ inh plasma levels between 5 and $30 \%$ of normal instead of the $50 \%$ expected from the expression of a single normal allele are still unknown. An increased catabolism of the normal $\mathrm{Cl}$ inh protein was found in HAE patients (39). Recently, studies on patients fibroblasts suggested that certain mutant CI-INH alleles may trans-inhibit the expression of the normal product at a pretranslational (40) or translational level (Rajczy, K., F. S. Rosen, and R. C. Strunk, communication at the 3rd International workshop on C1 Mainz, Germany [1992]). It is tempting to speculate that some of the mutants defective in intracellular transport might negatively affect the transport of the normal protein. We tested the possibility of posttranslational trans-inhibition in Cos-7 or $\mathrm{L}^{-\mathrm{TK}^{-}}$) cells transiently cotransfected with several combinations of normal and R472stop cDNA plasmids (data not shown). Indeed, in Cos-7 cells, a reduction of expression of the wild-type $\mathrm{C} 1$ inh was observed when the mutant protein was overexpressed, but cotransfection with a C4 control cDNA showed the phenomenon to be pleiotropic unlike the in vivo phenotype. When proteins were expressed at much lower levels as it is the case in transfected $\mathrm{L}\left(\mathrm{TK}^{-}\right)$ cells, no significant trans-inhibition was detected. Most likely, posttranslational trans-inhibition does not contribute in general to the low plasma levels of type I patients, although it may occur

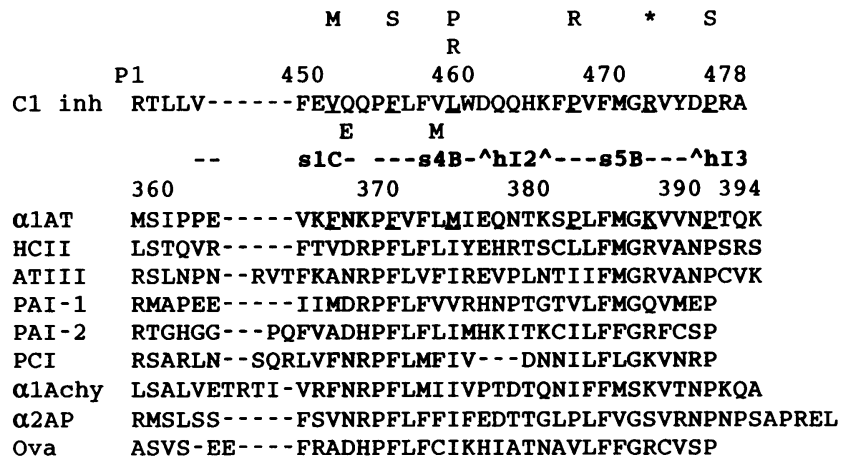

Figure 9. Amino acid alignment for the $\mathrm{COOH}$-terminal region of ten members of the serpin family. The sequences shown are from: human C1-inhibitor ( $C l$ inh), human $\alpha 1$-antitrypsin $(\alpha 1 A T)$, human heparin cofactor II (HCII), human antithombin III (ATII), human endothelial plasminogen activator inhibitor I (PAI-1), human placental plasminogen activator inhibitor, type II (PAI-2), human protein $\mathrm{C}$ inhibitor $(P C I)$, human $\alpha 1$-antichymotrypsin ( $\alpha 1$ lAchy), human $\alpha 2$-antiplasmin ( $\alpha 2 A P)$, and ovalbumin $(O v a)$. Numbering is given for $\mathrm{C} 1$-inhibitor and $\alpha 1$ antitrypsin and secondary structural elements of $\alpha 1$-antitrypsin are indicated with boldfaced characters above its sequence. Changes affecting $\mathrm{Cl}$ inh secretion and function are indicated above the $\mathrm{Cl}$ inh sequence and the corresponding normal residues of $\mathrm{Cl}$ inh and $\alpha 1$-antitrypsin are underlined. Changes with no effect on protein structure/function are indicated below the sequence. The asterisk represents a stop codon.

in vivo, depending on the cell type, the level of expression, the structure and the intracellular stability of the mutant protein.

Separate expression of each of the two changes found in the patient with the double point mutation showed that the L459R mutation, which affects a rather conserved residue (see Fig. 9), is responsible for the defective transport of the protein while the Q452E mutation, though introducing a charged residue, has no effect on protein expression. Moreover, this mutation does not seem to alter the main properties of the reactive site loop, as the Q452E mutant protein forms apparently normal complexes with C1s (Fig. 8). From amino acid alignments of the serpins (Fig. 9) it is in fact apparent that $\mathrm{Cl}$ inh is the only member of the family having a glutamine at this position, while all other serpins have an asparagine or an aspartic acid. Thus, the Q452E change found in the C1-INH gene recapitulates, to a certain extent, the asparagine/aspartic acid variation at this position in the serpin family.

Pulse-chase experiments demonstrated that intracellular mutant proteins were only partially glycosylated, indicating an early block in transport. This was confirmed by the results of the endo $\mathrm{H}$ treatment (Fig. 5). All mutant proteins accumulated within the cell over a $5 \mathrm{~h}$ period were sensitive to endo $\mathrm{H}$, suggesting that they had not been transported to the medial stacks of the Golgi apparatus where $\mathrm{N}$-linked sugars are processed to endo $\mathrm{H}$ resistant forms (30). By using double-label immunofluorescence microscopy the retention of the mutant proteins in early compartments was confirmed and additional differences in the intracellular fate of the mutant proteins were detected. Those which are not secreted or secreted only as traces were divided into two subgroups according to the staining pattern. The Q452E+L459R and R472stop proteins both yielded a typical ER staining pattern (type 2 in Figs. 6 and 7), whereas mutant proteins F455S, L459P, and P467R were also found in 
a compartment corresponding to the periphery of the area stained by WGA and thus topologically closely related to the Golgi apparatus (type 3 in Figs. 6 and 7). The ER appears to play a "quality control" role on the newly synthesized proteins which leads to retention and/or degradation of misfolded, unassembled or aggregated proteins. Although most of the studies on nonlysosomal, pre-Golgi degradation concern membrane proteins $(41-46)$, the same quality control mechanism was reported for some soluble luminal proteins. Numerous variants of $\alpha 1$-antitrypsin ( $\alpha 1-\mathrm{AT})$, the prototype of the serpin family, are retained and degraded within the cell (for review see reference 47). It was shown that the PiNull ${ }_{\text {Hong Kong }}$ and the PiZ mutants are retained and degraded in early compartments $(48,49)$. The unassembled immunoglobulin $\kappa$ light chain (50), secretory immunoglobulin $\mathbf{M}$ in B lymphocytes (51) and a frameshift mutant of $\beta$-hexosaminidase (52) were also shown to be degraded in a pre-Golgi compartment. Depending on the protein studied, proteolysis was reported to occur in the ER itself $(42,44)$ and/ or in a post-ER compartment $(46,49,51)$. Further experiments, at the ultrastructural level, are required to identify the site(s) of degradation of $\mathrm{C} 1$ inh mutant proteins. Moreover, it would be interesting to determine whether calnexin, a recently identified molecular chaperone that selectively associates with incompletely folded glycoproteins of the secretory pathway including $\alpha 1$-antitrypsin and $\alpha 1$-antichymotrypsin (53), is implicated in the retention and degradation of mutant $\mathrm{C} 1$ inh proteins.

The most likely explanation for the intracellular retention or degradation of $\mathrm{C} 1$ inh proteins mutated near the carboxyl end is that the mutations prevent the proteins from proper folding. Valine 451 is located, according to the antitrypsin model (54) in the $\beta$ sheet strand $1 \mathrm{C}$. The V451M substitution, although affecting a residue not strictly conserved among serpins (Fig. 9) and resembling the neutral polymorphism located 6 residues downstream (indicated below the $\mathrm{Cl}$ inh sequence in Fig. 9), does affect intracellular transport, even though not dramatically, indicating that valine 451 is important for folding of $\mathrm{Cl}$ inh into its native conformation. An alanine to threonine substitution was found at the same position in antithrombin III (ATIII) Paris 3 (55), in a patient with reduced antigenic plasma levels, suggesting that it was not normally secreted. Amino acid substitutions at other positions of strand 1C of ATIII have also been found in patients with reduced antigenic plasma levels (55). The other $\mathrm{C} 1$ inh mutation leading to a partially secreted protein which also accumulates within the cell is the replacement of proline 476 by the polar serine. According to the antitrypsin model, proline 476 is internal, close to the conserved F293 (F208 in $\alpha 1-\mathrm{AT}$ coordinates) and initiates the one turn $\mathrm{COOH}-$ terminal helix (54) of $\mathrm{Cl}$ inh. The absolute conservation of this proline in the serpin family (see Fig. 9) also suggests that P476 is necessary for the serpins to adopt their native conformation. In vitro mutagenesis experiments have indeed shown that truncation of $\alpha 1$-AT immediately before proline 391 (equivalent to P476 of $\mathrm{C} 1$ inh) reduces transport from the ER to the Golgi apparatus and that truncation immediately after P391 has no effect on secretion (56). Thus, it is not surprising that the truncated R472stop $\mathrm{Cl}$ inh is rapidly degraded in the ER. The proline equivalent to $\mathrm{P} 476$ of $\mathrm{C} 1$ inh was also found to be a leucine in ATIII in a patient with severe thromboembolic episodes (57). However, the antigenic plasma levels were normal, suggesting that this particular substitution does not affect intracellular transport of antithrombin III. Phenylalanine 455, which was found replaced by a serine, is also invariant in the serpin family. This residue, as well as leucine 459 , proline 467 and arginine $\mathbf{4 7 2}$ are located, according to the antitrypsin model, in strands 4 or 5 of the $\beta$ sheet $B$ which is one of the most conserved features of serpins (54). Given the nature of the mutations affecting these residues it is more than likely that folding of the mutant proteins is dramatically affected. Substitution, in strand 5B (Fig. 9), of the conserved glycine residue with arginine has been recently described in a pathogenic ATIII mutant, but the molecular consequences of this change have not been described (58).

Defects of intracellular transport and secretion represent one of the major groups among the biochemical abnormalities produced by mutations in the $C I I N H$ gene. In addition to the examples described here, deletions of exon 4, observed in several families (19), determine the production of a mutant protein with an internal in phase deletion of 45 amino acids, which is also blocked at early stages of its intracellular transport (59). In the case of mutants V451M and P476S, which accumulate intracellularly but are also partially secreted, intracellular folding is probably much closer to wild-type than with the other pathogenic mutants described here. However, lack of recognition of the secreted fraction of V451M and P476S C1 inh by the target protease $\mathrm{Cls}$ (Fig. 8) indicates that the reactive center arginine is not properly exposed. Amino acid changes in other domains of $\mathrm{C} 1$ inh may also result in secretion of lower than normal levels of a dysfunctional protein. Considering the variety of mutations detected in different exons of the C1-INH gene of HAE patients (reference 29 and our own unpublished data), it is likely that additional mutations, possibly in other exons, also determine a phenotype combining the features of type I and type II HAE.

\section{Acknowledgments}

This article is dedicated to the memory of Pierre Bourgarel for his fundamental contributions to $\mathrm{Cl}$ inhibitor studies.

We wish to thank Raymond Hellio for his skillful help in confocal microscopy and Drs. Jacques Cohen and Jérôme Laurent for providing blood samples of patients. Dr. Susan Clark Bock donated the full-length cDNA clone used in our initial expression studies. Catherine Bazzali, Chistiane Duponchel, and Pierre Bourgarel helped in the initial experiments.

This work was supported by grants from the Caisse Nationale de l'Assurance Maladie des Travailleurs Salariés (CNMTS), the Mutuelle Générale de l'Education Nationale (MGEN), the Ministère de la Recherche et de la Technologie, and the Groupement de Recherches et d'Etudes sur les Génomes.

\section{References}

1. Tosi, M., C. Duponchel, P. Bourgarel, M. Colomb, and T. Meo. 1986. Molecular cloning of $\mathrm{C} 1$ inhibitor: sequence homologies with $\alpha 1$-antitrypsin and other members of the serpins superfamily. Gene. 42:265-272.

2. Bock, S. C., K. Skriver, E. Nielsen, H.-C. Th $\phi$ gersen, B. Wiman, V. H. Donaldson, R. L. Eddy, J. Marrinan, E. Radziejewska, R. Huber, T. B. Shows, and S. Magnusson. 1986. Human C1 inhibitor: primary structure, cDNA cloning, and chromosomal localization. Biochemistry. 25:4292-4301.

3. Carter, P. E., B. Dunbar, and J. E. Fothergill. 1988. Genomic and cDNA cloning of the human $\mathrm{Cl}$ inhibitor. Intron-exon junctions and comparison with other serpins. Eur. J. Biochem. 173:163-169.

4. Loebermann, H., R. Tokuoka, J. Deisenhofer, and R. Huber. 1984. Human alpha-1-proteinase inhibitor. Crystal structure analysis of two crystal modifications, molecular model and preliminary analysis of the implications for function. J. Mol. Biol. 177:531-556. 
5. Carrel, R. W., and M. C. Owen. 1985. Plakalbumin, $\alpha 1$-antitrypsin, antithrombin and the mechanism of inflammatory thrombosis. Nature (Lond.). 317 $730-732$.

6. Cooper, N. R. 1985. The classical complement pathway: activation and regulation of the first complement component. Adv. Immunol. 37:151-216.

7. Davis, A. E., III. 1988. C1 inhibitor and hereditary angioneurotic edema. Ann. Rev. Immunol. 6:595-628.

8. Stoppa-Lyonnet, D., M. Tosi, J. Laurent, A. Sobel, G. Lagrue, and T. Meo. 1987. Altered $\mathrm{Cl}$ inhibitor genes in type I hereditary angioedema. N. Engl. J. Med. 317:1-6.

9. Rosen, F. S., P. Charache, J. Pensky, and V. Donaldson. 1965. Hereditary angioneurotic edema: two genetic variants. Science (Wash. DC). 148:957-958.

10. Carter, P. E., C. Duponchel, M. Tosi, and J. E. Fothergill. 1991. Complete nucleotide sequence for the $\mathrm{C} 1$ inhibitor with an unusually high density of $A l u$ elements. Eur. J. Biochem. 197:301-308.

11. Aulak, K. S., P. A. Pemberton, F. S. Rosen, R. W. Carrel, P. J. Lachmann, and R. A. Harrison. 1988. Dysfunctional C1-inhibitor (At), isolated from a type II hereditary-angio-oedema plasma, contains a P1 'reactive center' ( $\mathrm{Arg}^{444} \rightarrow \mathrm{His}$ ) mutation. Biochem. J. 253:615-618.

12. Skriver, K., E. Radziejewska, J. A. Silbermann, V. H. Donaldson, and S. C. Bock. 1989. CpG mutations in the reactive site of human C1-Inhibitor. $J$. Biol. Chem. 264:3066-3071.

13. Aulak, K. S., M. Cicardi, and R. A. Harrison. 1990. Identification of a new $\mathrm{P} 1$ residue mutation (444Arg $\rightarrow \mathrm{Ser}$ ) in a dysfunctional $\mathrm{Cl}$ inhibitor protein contained in a type II hereditary angioedema plasma. FEBS (Fed. Eur. Biochem. Soc.) Lett. 266:13-16.

14. Frangi, D., K. S. Aulak, M. Cicardi, R. A. Harrison, and A. E. Davis III. 1992. A dysfunctional $C 1$ inhibitor protein with a new reactive center mutation (Arg-444 $\rightarrow$ Leu). FEBS (Fed. Eur. Biochem. Soc.) Lett. 301:34-36.

15. Levy, N. J., N. Ramesh, M. Cicardi, R. A. Harrison, and A. E. Davis III 1990. Type II hereditary angioneurotic edema that may result from a single nucleotide change in the codon for alanine- 436 in the $\mathrm{C} 1$ inhibitor gene. Proc Natl. Acad. Sci. USA. 87:265-268.

16. Skriver, K., W. R. Wikoff, P. A. Patston, F. Tausk, M. Schapira, A. P. Kaplan, and S. C. Bock. 1991. Substrate properties of C1 inhibitor Ma (alanine 434 glutamic acid). J. Biol. Chem. 266:9216-9221.

17. Davis, A. E., III, K. Aulak, R. B. Parad, H. P. Stecklein, E. Eldering C. E. Hack, J. Kramer, R. C. Strunk, J. Bissler, and F. S. Rosen. 1992. C1 inhibito hinge region mutations produce dysfunction by different mechanisms. Nature Genetics. 1:354-358.

18. Parad, R. B., J. Kramer, R. C. Strunk, F. S. Rosen, and A. E. Davis III 1990. Dysfunctional C1 inhibitor Ta: deletion of Lys-251 results in acquisition of an N-glycosylation site. Proc. Natl. Acad. Sci. USA. 87:6786-6790.

19. Stoppa-Lyonnet, D., C. Duponchel, T. Meo, J. Laurent, P. E. Carter, M Arala-Chaves, J. H. M. Cohen, G. Dewald, J. Goetz, G. Hauptman, G. Lagrue, P. Lesavre, M. Lopez-Trascasa, G. Misiano, C. Moraine, A. Sobel, P. J. Späth and M. Tosi. 1991. Recombinational biases in the rearranged C1-Inhibitor genes of hereditary angioedema patients. Am. J. Hum. Genet. 49:1055-1062.

20. Grompe, M., D. M. Muzny, and C. T. Caskey. 1989. Scanning detection of mutations in human ornithine transcarbamoylase by chemical mismatch cleavage. Proc. Natl. Acad. Sci. USA. 86:5888-5892.

21. Cotton, R. G. H., N. R. Rodrigues, and R. D. Campbell. 1988. Reactivity of cytosine and thymine in single-base-pair mismatches with hydroxylamine and osmium tetroxide and its application to the study of mutations. Proc. Natl. Acad. Sci. USA. 85:4397-4401.

22. Eldering, E., J. H. Nuijens, and C. E. Hack. 1988. Expression of functiona human $\mathrm{C1}$ inhibitor in COS cells. J. Biol. Chem. 263:11776-11779.

23. Higuchi, R., B. Krummel, and R. K. Saiki. 1988. A general method of in vitro preparation and specific mutagenesis of DNA fragments: study of protein and DNA interactions. Nucleic Acids Res. 16:7351-7367.

24. Sambrook, J., E. F. Fritsch, and T. Maniatis. 1989. Molecular Cloning: A Laboratory Manual, 2nd Ed. Cold Spring Harbor Laboratory Press, Cold Spring Harbor, NewYork.

25. Turner, J. M., M. H. Brodsky, B. A. Irving, S. D. Levin, R. M. Perlmutter, and D. R. Littman. 1990. Interaction of the unique $\mathrm{N}$-terminal region of tyrosine kynase p56 ${ }^{\text {lck }}$ with cytoplasmic domains of CD4 and CD8 is mediated by cystein motifs. Cell. 60:755-765.

26. Salerno, G., P. Verde, M. L. Nolli, A. Corti, H. Szöts, T. Meo, J. Johnson, S. Bullock, G. Cassani, and F. Blasi. 1984. Monoclonal antibodies to urokinase identify the single-chain pro-urokinase precursor. Proc. Natl. Acad. Sci. USA. 81:110-114.

27. Eldering, E., C. C. M. Huijbregts, Y. T. P. Lubbers, C. Longstaff, J. H. Nuijens, and C. E. Hack. 1992. Characterization of recombinant $\mathrm{Cl}$ inhibitor P1 variants. J. Biol. Chem. 267:7013-7020.

28. Nuijens, J. H., A. J. M. Eerenberg-Belmer, C. C. M. Huijbregts, W. O. Schreuder, R. J. F. Felt-Bersma, J. J. Abbink, L. G. Thijs, and C. E. Hack. 1989 Proteolytic inactivation of plasma $\mathrm{C1}$ inhibitor in sepsis. J. Clin. Invest. 84:443450 .
29. Verpy, E., M. Biasotto, T. Meo, and M. Tosi. 1994. Efficient detection of point mutations on color-coded strands of target DNA. Proc. Natl. Acad. Sci. USA. 91:1873-1877.

30. Kornfeld, R., and S. Kornfeld. 1976. Comparative aspects of glycoprotein structure. Annu. Rev. Biochem. 45:217-238.

31. Hsu, V. W., N. Shah, and R. D. Klausner. 1992. A brefeldin A-like phenotype is induced by the overexpression of a human ERD-2-like protein, ELP 1. Cell. 69:625-635.

32. Virtanen, I., P. Ekblom, and P. Laurila. 1980. Subcellular compartmentalization of saccharide moities in cultured normal and malignant cells. J. Cell Biol. 85:429-434.

33. Cugno, M., J. Nuijens, E. Hack, A. Eerenberg, D. Frangi, A. Agostoni, and M. Cicardi. 1990. Plasma levels of $\mathrm{Cl}$ inhibitor complexes and cleaved C inhibitor in patients with hereditary angioneurotic edema. J. Clin. Invest. 85:12151220 .

34. Aulak, K. S., E. Eldering, C. E. Hack, Y. P. T. Lubbers, R. A. Harrison A. Mast, M. Cicardi, and A. E. Davis III. 1993. A hinge region mutation in C1inhibitor $\left(\mathrm{Ala}^{436} \Rightarrow \mathrm{Thr}\right.$ ) results in nonsubstrate-like behaviour and in polymerization of the molecule. J. Biol. Chem. 268:18088-18094.

34a. Eldering, E., E. Verpy, T. Meo, and M. Tosi. 1994. The C-terminus of the serpin $\mathrm{C} 1$ inhibitor contains crucial residues that prevent spontaneous insertion of the reactive centre loop. Keystone Symposia on Molecular \& Cellular Biology. J. Cell. Biochem. 18D (Suppl.):54 (Abstr.)

34b. Eldering, E., E. Verpy, D. Roem, T. Meo, and M. Tosi. 1995. C-termina substitutions in the serpin $\mathrm{Cl}$ inhibitor that cause loop overinsertion and subsequent multimerization. J. Biol. Chem. In press.

35. Siddique, Z., A. R. McPhaden, and K. Whaley. 1992. Type II hereditary angio-oedema associated with two mutations in one allele of the $\mathrm{Cl}$-inhibito gene around the reactive-site coding region. Hum. Hered. 42:298-301.

35a. Bissler, J. J., V. H. Donaldson, and A. E. Davis III. 1994. Contiguous deletion and duplication mutations resulting in type I hereditary angioneurotic edema. Hum. Genet. 93:265-269.

36. Frangi, D., M. Cicardi, A. Sica, F. Colotta, A. Agostini, and A. E. Davis III. 1991. Nonsense mutations affect $\mathrm{Cl}$ inhibitor messenger RNA levels in patients with type I hereditary angioneurotic edema. J. Clin. Invest. 88:755-759.

37. Siddique, Z., A. R. McPhaden, D. McCluskey, and K. Whaley. 1992. A single base deletion from the $\mathrm{C} 1$-inhibitor gene causes type I hereditary angiooedema. Hum. Hered. 42:231-234.

38. Siddique, Z., A. R. McPhaden, J. E. Fothergill, and K. Whaley. 1993. A point mutation in the $\mathrm{C} 1$-inhibitor gene causes type $\mathrm{I}$ hereditary angio-oedema. Hum. Hered. 43:155-158.

39. Quastel, M., R. Harrison, M. Cicardi, C. A. Alper, and F. S. Rosen. 1983. Behaviour in vivo of normal and disfunctional $\mathrm{Cl}$ inhibitor in normal subjects and patients with hereditary angioneurotic edema. J. Clin. Invest. 71:1041-1046.

40. Kramer, J., Y. Katz, F. S. Rosen, A. E. Davis III, and R. C. Strunk. 1991 Synthesis of $\mathrm{Cl}$ inhibitor in fibroblasts from patients with type I and type II hereditary angioneurotic edema. J. Clin. Invest. 87:1614-1620.

41. Lippincott-Schwartz, J., J. S. Bonfacino, L. C. Yuan, and R. D. Klausner 1988. Degradation from the endoplasmic reticulum: disposing of newly synthesized proteins. Cell. 54:209-220.

42. Stafford, F. J., and J. S. Bonifacino. 1991. A permeabilized cell system identifies the endoplasmic reticulum as a site of protein degradation. J. Cell Biol. 115:1225-1236.

43. Amara, J. F., G. Lederkremer, and H. F. Lodish. 1989. Intracellular degradation of unassembled asialoglycoprotein receptor subunits: a pre-Golgi, nonlysosomal endoproteolytic cleavage. J. Cell Biol. 109:3315-3324.

44. Wikström, L., and H. F. Lodish. 1992. Endoplasmic reticulum degradation of a subunit of the asialoglycoprotein receptor in vitro. J. Biol. Chem. 267:5-8.

45. Esser, V., and D. W. Russell. 1988. Transport-deficient mutations in the low density lipoprotein receptor. J. Biol. Chem. 263:13276-13281.

46. Tsao, Y. S., N. E. Ivessa, M. Adesnik, D. D. Sabatini, and G. Kreibich 1992. Carboxy terminally truncated forms of ribophorin I are degraded in preGolgi compartments by a calcium-dependent process. J. Cell Biol. 116:57-67.

47. Crystal, R. G. 1990. $\alpha 1$-antitrypsin deficiency, emphysema, and liver disease. J. Clin. Invest. 85:1343-1352.

48. Sifers, R. N., S. Brashears-Macatee, V. J. Kidd, H. Muensch, and S. L. C. Woo. 1988. A frameshift mutation results in a truncated $\alpha 1$-antitrypsin that is retained whithin the rough endoplasmic reticulum. J. Biol. Chem. 263:73307335 .

49. Le, A., K. S. Graham, and R. N. Sifers. 1990. Intracellular degradation of the transport-impaired human PiZ $\alpha 1$-antitrypsin variant. J. Biol. Chem. 265:14001-14007.

50. Gardner, A. M., S. Aviel, and Y. Argon. 1993. Rapid degradation of an unassembled immunoglobulin light chain is mediated by a serine protease and occurs in a pre-Golgi compartment. J. Biol. Chem. 268:25940-25947.

51. Amitay, R., I. Shachar, E. Rabinovich, J. Haimovich, and S. Bar-Nun. 1992. Degradation of secretory immunoglobulin M in B lymphocytes occurs in 
a postendoplasmic reticulum compartment and is mediated by a cysteine protease. J. Biol. Chem. 267:20694-20700.

52. Lau, M. M. H., and E. F. Neufeld. 1989. A frameshift mutation in a patient with Tay-Sachs disease causes premature termination and defective intracellular transport of the $\alpha$-subunit of $\beta$-hexosaminidase. J. Biol. Chem. 264:2137621380 .

53. Ou, W. -J., P. H. Cameron, D. Y. Thomas, and J. J. M. Bergeron. 1993 Association of folding intermediates of glycoproteins with calnexin during protein maturation. Nature (Lond.). 364:771-776.

54. Huber, R., and R. W. Carrell. 1989. Implications of the three-dimentional structure of $\alpha 1$-antitrypsin for structure and functions of serpins. Biochemistry. 28:8951-8966.

55. Lane, D. A., R. J. Olds, J. Conard, M. Boisclair, S. C. Bock, M. Hultin U. Abildgaard, H. Ireland, E. Thompson, G. Sas, M.-H. Horellou, G. Tamponi, and S.-L. Thein. 1992. Pleiotropic effects of antithrombin strand 1C substitution mutations. J. Clin. Invest. 90:2422-2433.

56. Brodbeck, R. M., and J. L. Brown. 1992. Secretion of $\alpha 1$-proteinase inhibitor requires an almost full length molecule. J. Biol. Chem. 267:294-297.

57. Olds, R. J., D. A. Lane, R. Caso, M. Panico, H. R. Morris, G. Sas, J. Dawes, and S. L. Thein. 1992. Antithrombin III Budapest: a single amino acid substitution (429Pro to Leu) in a region highly conserved in the serpin family. Blood. 79:1206-1212.

58. Jochmans, K., W. Lissens, R. Vervoort, S. Peeters, M. De Waele, and I. Liebaers. 1994. Antithrombin-Gly 424 Arg: a novel point mutation responsible for type 1 antithrombin deficiency and neonatal thrombosis. Blood. 83:146-151. 59. Tosi, M., P. Bourgarel, C. Bazzali, C. Duponchel, D. Stoppa-Lyonnet, and T. Meo.1990. Intracellular retention of $\mathrm{Cl}$ inhibitor in two hereditary angioedema patients. Complement Inflammation. 7:2119. 